\title{
Identity and Fraud: Underscoring the Performance of Companies that have adopted the use of the Ugandan National Identity Card and those that have not
}

\author{
Dr. Josephine Apili Ali \\ D.B.A
}

\begin{abstract}
National Identity Cards is one of the assessment tools for identifying identity fraud in Companies. Its assumptions are premised on the due process of enrolment for the registration of persons.
\end{abstract}

Key Words: National Identity Cards; performance measurement; identity fraud; benefit of the Company; Uganda.

\section{Introduction}

The notion of person identification and identity fraud is becoming an area of concern globally. Clarke (1994) defines human identification as the association of data with a particular human being. And further that personal identification concerns the practical way in which individuals are identified in various contexts. According to Thompson (2004), identity is critical in ensuring trusted on-line transactions. Identity Fraud occurs when someone uses personal information gained about another person to impersonate that person (Beynon, 2007). Beynon (2007) also asserts that the use of National Identity Cards can help combat identity fraud.

Uganda is a landlocked Country in East Africa and a Partner State of the East African Community-a Regional Economic Group of States in East Africa. The Treaty for the establishment of the East African Community; the Protocol on the Establishment of the East African Community Common Market and the Constitution of the Republic of Uganda, 1995, guides its operations-providing for a civil registration and a vital statistics system to register citizens and resident foreign nationals. While Uganda may not have concrete data on what identity fraud is currently estimated to cost to Government and to the private sector, it is evident that the cost has touched the business sector in terms of nontrusted online transactions; irregular immigration and its consequences in the private sector-ranging from among others xenophobia; terrorism, increased crime (the recent increased murders that remain unresolved ("Murders" 2018). This is against the backdrop that these incidences affect the conduciveness of the environment for doing business and ultimately the business performance.

This study therefore aims to look at the Uganda National Identity Card's impacts on combating identity fraud and enhancing business performance in Companies. Contextually, Performance measurement, the process of setting key drivers in order to assess, evaluate and change (if applicable) core business objectives (Tucker and Pitt, 2009) is thus very key in this research.

\section{The Enrolment Process for the Registration of the Uganda National Identity Card}

According to the NGO Forum, (2014) and Karugaba and Walubiri (2015), the process of mass enrolment commenced in April 2014, under a two-year project, code named "My Country, My Identity".

The mass enrolment culminated into the creation of a legal and regulatory framework for the issuance of the National Identity Card under the Registration of Persons Act, 2015, which is now fully operational. This Act consolidated some laws for registration of births, marriages and deaths among others, into one primary legislation and created an office (the National Identification and Registration Authority (NIRA), to handle the administrative and operational procedures for the issuance of the Uganda National Identity Card and Identification Cards for Resident Foreign Nationals.

The 2015 Act also creates linkages with the following institutions that register persons for other lawful purposes: Uganda Registration Services Bureau (for companies), the Electoral Commission and the Uganda Revenue Authority (tax Administration). The Integrated Personnel and Payroll System, the Integrated Financial Management System and the mobile phone networks have been integrated with the National Identity Card system. On $29^{\text {th }}$ May, 2017, NIRA started registering children aged 0-5 years for purposes of giving them National Identification Numbers (NIN), pending the issuance of National Identity Cards when they reach 16 years of age ("Students", 2017; Kwesiga, 2018). Indeed, as of $31^{\text {st }}$ December 2017, 10.5 million learners had been registered. 
Further, (Kahungu, 2019) indicated that by January 2019, out of 17.5 million cards that NIRA had been printed, 14.6 million cards had been issued by January 2019, leaving a pending lot of 2.2 million cards that have not yet been picked by their owners. NIRA also started a three months' mass enrolment at sub county level and the five divisions of the Capital City effective $11^{\text {th }}$ February 2019.This exercise will cover registration of citizens for the national register; issuance of National Identification Numbers and sorting out queried cases (Kahungu, 2019).

\section{Methodology and Scope}

This research paper upheld research ethics and used case studies of four Companies, with two in the Sports Industry and two in the Telecommunication Industry. The former Companies have not adopted the use of National Identity Cards, while the latter have adopted the use of National Identity Cards. The Researcher also used cross-sectional surveys, questionnaires, interview and samples. A triangulation of quantitative and qualitative research designs (Robson, 2002) was used.

\section{The Company Profiles}

The research was conducted in two of the largest SMEs in the sports sector: Adidas Uganda Limited and Asiatic Sports Center Limited. The research was also conducted in two of Uganda's main telecommunication companies: MTN (U) Limited and Airtel (U) Limited.

\section{The Problem Statement}

Identity fraud has been portrayed as one of the ways of precipitating fraud (Beynon, 2007). Uganda has just recently launched the third party interface where both public and private institutions are linked to the National Identity Card database. The telecommunication companies were also recently issued with card readers to enable them identify the exact holder of the National Identity Card in the course of their work. This gap analysis is therefore to establish the impact of person identification in curbing fraud and enhancing business performance in Companies.

\section{Literature Review}

\section{Introduction}

The section looks at what encompasses the pre enrolment process for the registration of the National Identity Card; the need for re-identification; the use of transactional data and how the National Identity Card can be used as a performance measure.

\section{The Assumptions:}

\section{The Pre-Enrolment Process}

This subsection looks at the pre- enrolment process and how it was handled from the onset. In this context, this process includes authentication which entails citizenship verification; identification and then lastly enrolment (Beynon, 2007). According to the NGO Forum (2014) and Karugaba and Walubiri (2015), the enrolment, registration and issuance of the National Identity Cards was undertaken within the two-year Project period.

Specifically, the process of mass enrolment commenced in April 2014, with registration of citizens aged 16 years and above, by capturing their data biometrically, with a view to issuing them with National Identity Cards by September, 2014. As of August $9^{\text {th }}, 2014$, of the estimated 15.9 million citizens above the age of 16 years, 14 million had been registered. By September $4^{\text {th }} 2014,14.8$ million citizens had been registered and the number increased to at least 15 million by December $12^{\text {th }}, 2014$, with more than 100,000 National Identity Cards issued. The registration process was thus largely successful with 78\% success rate after mass enrolment and $96 \%$ success rate before the general elections in February, 2016. Notably, several Ugandans used National Identity Cards for the first time to vote in the 2016 general elections. The citizenship verification, identification and enrolment was carried out concurrently prior to registration of persons and issuance of National Identity Cards.

The question however, remains as to whether the information regarding persons' identities that was captured during the pre enrolment process was authentic. The study will thus establish the impact of the Uganda National Identity Card in curbing fraud and enhancing business performance.

\section{Re- identification}

There is need for verification of the information provided by citizens for purposes of any registration whether with mobile phone companies or otherwise. 
Indeed, there is further citizenship verification being conducted with the Directorate of Citizenship and Immigration Control, to ascertain the authenticity of the data collected by NIRA for purposes of issuance of passports among others (Bwambale, 2018).

On $14^{\text {th }}$ April, 2018, the National Identity Card Registration Authority distributed card readers to Telecommunication Companies for purposes of verification and confirmation of the registered phone user's identity. Further, on May 7 , 2018, NIRA launched the Third Party Interface, a platform that will allow NIRA to share people's data with all Ministries, Departments, Agencies and telecommunication companies for this purpose (Wassajja, 2018).

However, according to data from the NIRA website, 2015, they had received several cases where the National Identity Cards are being held irregularly and in accordance with the law they intend to handle it through a Tribunal that is yet to be established. Furthermore, in the recent past, fraudsters have used personal information from the unsuspecting owner's identity cards to register telephone lines, which were used for communication purposes in hideous crimes like the murder of a Ugandan, lady the late Magara. Indeed, ("Murders" 2018), reported that five people were remanded to Luzira Prisons after appearing before the Makindye Grade One Court for irregularly registering SIM cards using other people's National Identity Card particulars for use in criminal activities.

\section{The Importance of Transactional data.}

A necessary component of this research, transactional data is data that records events taking place between individuals and groups and organizations. Transactional data is typically important to the running of most organizations and markets and (Zuboff, 1988) has shown the possibility for "informatisation" that the capture and processing of such data brings. Seifert (2004), asserts that by using technologies such as data warehousing and data mining, transactional data can be combined with identification data such as peoples' age and place of birth, to permit both public and private sector organizations to make decisions about the planning of their work.

\section{Performance Measurement}

A performance measurement system is more than just a collection of measures, as it includes basic elements like people, data, software and hardware (Wettstein and Kueng, 2002). Additionally, integrity is also one of the key characteristics of a performance measurement system (Cocca \& Alberti, 2010). Further, the measurement/assessment should be dynamic, updated and has to be modified as circumstances change so that the performance measures remain relevant (Lynch and Cross, 1991).

An effective/robust civil registration system, with the National Identity Card as the national identifier can streamline and measure managerial systems and enhance performance in Companies. This is against the backdrop that the Uganda National Identity Card encompasses all the elements mentioned immediately above. As regards integrity, the Uganda National Identity Card enforces sustainability of business success by upholding ethical concepts in improving business processes in terms of a quicker service to known customers, quality of product as well as increased profits. And research shows that there is a direct relationship between performance and the quality of service offered in organizations (Darmail, Sadorsky and Henrique Irlue, 2009).

The National Identity Card can thus be used to establish whether more specific identification of customers can enhance business performance through customer and market segmentation and reduction of fraud. This research therefore seeks to establish whether an effective registration process of the Uganda National Identity Card can curb fraud and enhance the business performance of companies.

\section{Discussion and Findings}

\section{Discussion}

The section focuses on the demographic background, Correlations and Regression.

\section{Quantitative Report for Companies that have not adopted the use of National Identity Cards}

The study used the questionnaires to establish how National Identity Cards are utilized by Companies in Uganda in business segmentation and management of fraud. From the administered questionnaires, the following was established and reflected below: 


\begin{tabular}{|l|l|l|l|l|l|l|}
\hline Biodata & Variable & $\mathbf{\%}$ & Variable & $\mathbf{\%}$ & Variable & \% \\
\hline Sex & Female & $35.7 \%$ & Male & $64.3 \%$ & & \\
\hline Age & $18-29$ & $35.7 \%$ & $30-39$ & $50.0 \%$ & $40-49$ & $14.3 \%$ \\
\hline Education & Secondary & $21.4 \%$ & University & $64.3 \%$ & Post Graduate & $14.3 \%$ \\
\hline Income & $\begin{array}{l}\text { UGX 500,000 } \\
\text { Purchasing power }\end{array}$ & $42.9 \%$ & $\begin{array}{l}\text { UGX } \\
500,000999,000\end{array}$ & $21.4 \%$ & $1,000,000+$ & $35.7 \%$ \\
\hline Mode of payment & $\begin{array}{l}\text { Mobile money } \\
\text { and Cash }\end{array}$ & $0.0 \%$ & Cash & $42.9 \%$ & Yearly & $50.0 \%$ \\
& & & $100.0 \%$ & & \\
\hline
\end{tabular}

Table 1

\section{Source: Primary Data}

\section{Demographic Background}

Before collecting information regarding the objectives of the study, the background information of the respondents was sought by the study. This information was done in order to indicate the distribution of respondents in terms of their sex, age groups, highest attained education levels, income levels, categories, purchasing modes and the mode of payments for the services sought. The statistical presentation of this background information is presented in the following figures.

Sex of the respondents

The researcher was interested in the sex of the respondents and Fig.1 presents the findings.

Fig.1: Sex of the respondents

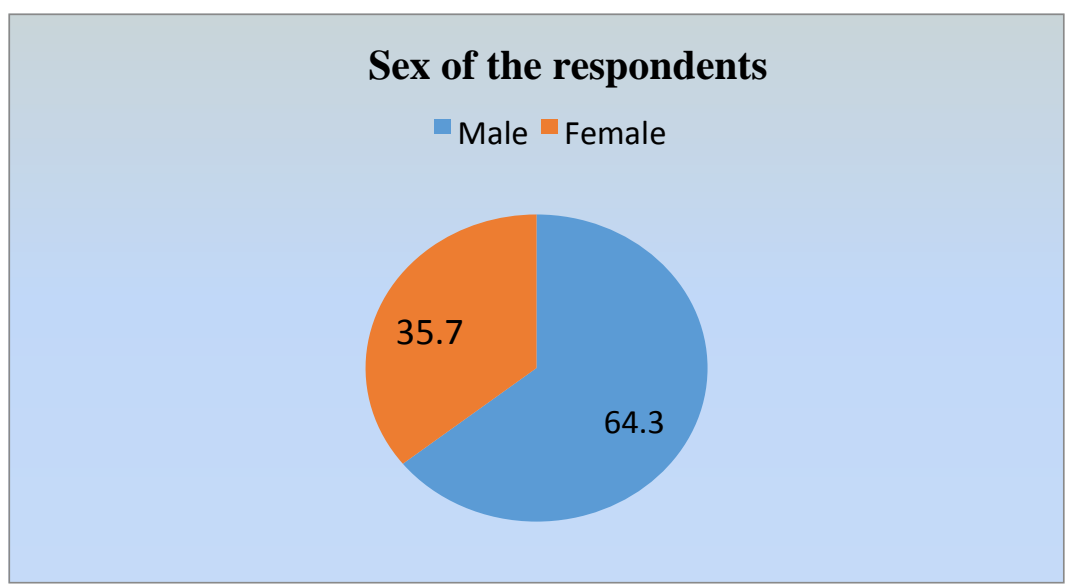

\section{Source: Primary Data}

From Fig.1, the findings indicate that from the randomly sampled respondents from among the clients that visit the sports companies, $64.3 \%$ were males while $35.7 \%$ were females. This implies that the majority of the respondents were males. This was so because most males are engaged in sports activities in Uganda. In addition, men in Uganda have more purchasing capacity than the female counterparts hence the higher percentage of men who are purchasing sportswear. Nevertheless, there was a fair representation of females in the study implying that females' inputs are part of the study findings.

Age of the respondents

Age was another factor that the researcher was interested in. This is because the researcher wanted to establish the age group that engages a lot in sporting activities and how it can be used in business segmentation in the sports manufacturing companies in Uganda. From the data gathered in the field, the findings are reflected in Fig. 2 below: 




Source: Primary data

Figure 2

The findings in Figure 2 indicate that majority of the respondents lie in the age bracket of 30-39 at 50\%. This implies that those between 30-39 years of age in Uganda have more purchasing power for sportswear. The study findings indicate that those that surpassed 40 years $(14.3 \%)$ are the least in the purchasing of sportswear hence limited involvement in sports activities.

Education levels of the respondents

The researcher established the education levels of the respondents. This was used as a yardstick to establish the attitudes of Ugandans towards their involvement in sporting activities. The findings are reflected in Figure 3 below:

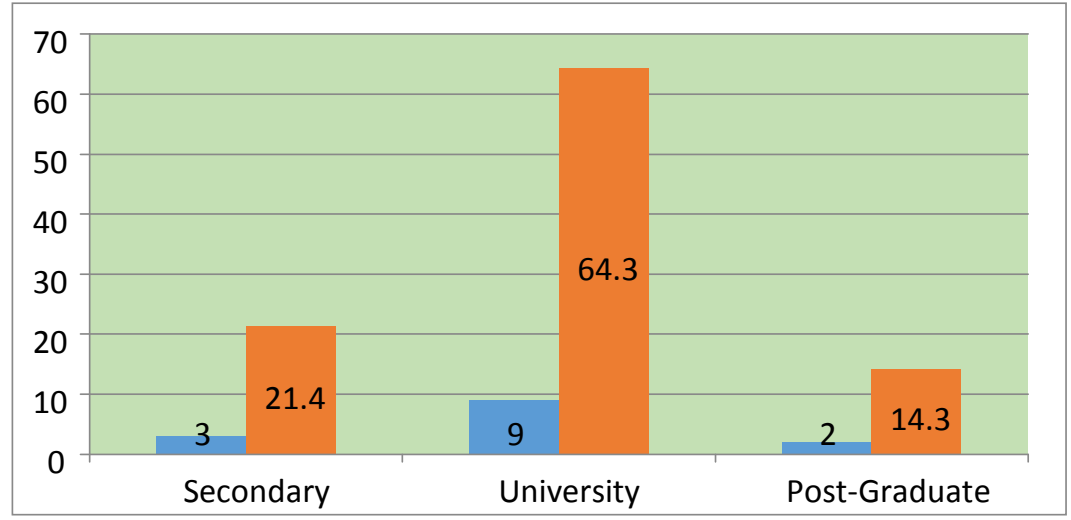

Figure 3

Source: Primary data

The findings in figure 3 indicate that the majority of the respondents at $64.3 \%$ had a university degree. When combined with those with a degree and postgraduate studies, the number increases to $78.6 \%$. This is an indicator that the data that was gathered from the respondents was generated from an informed point of view.

Income Levels of the respondents

The income of the respondents was used to establish how different income level earners are involved in purchasing of sportswear. From the gathered data, the findings are reflected below. 


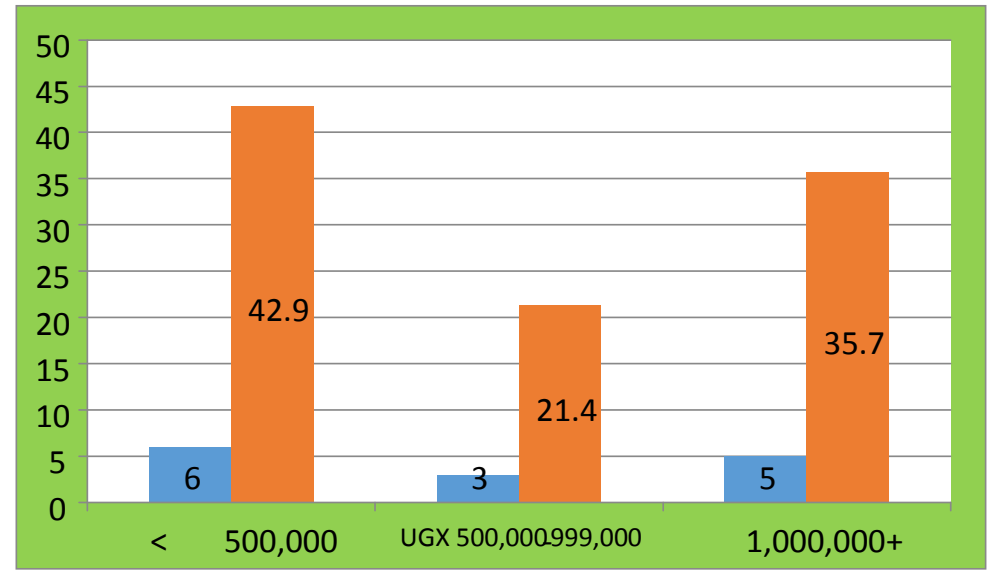

Source: Primary Data

Figure 4

The findings indicate that when combined, those that are earning above 500,000 Uganda shillings and those earning above 1,000,000 Uganda shillings in monthly income earnings, form the majority of the respondents at $57.1 \%$. This indicates that those with a relatively higher income above 500,000 Uganda shillings participate in purchasing and utilization of sportswear in Uganda.

\section{Purchasing Consistency}

It was part of the researcher's interest to find out how clients regularly purchase sportswear among the sport dealing companies in Uganda. From the administered questionnaires, the following was discovered as reflected in figure 5 below:

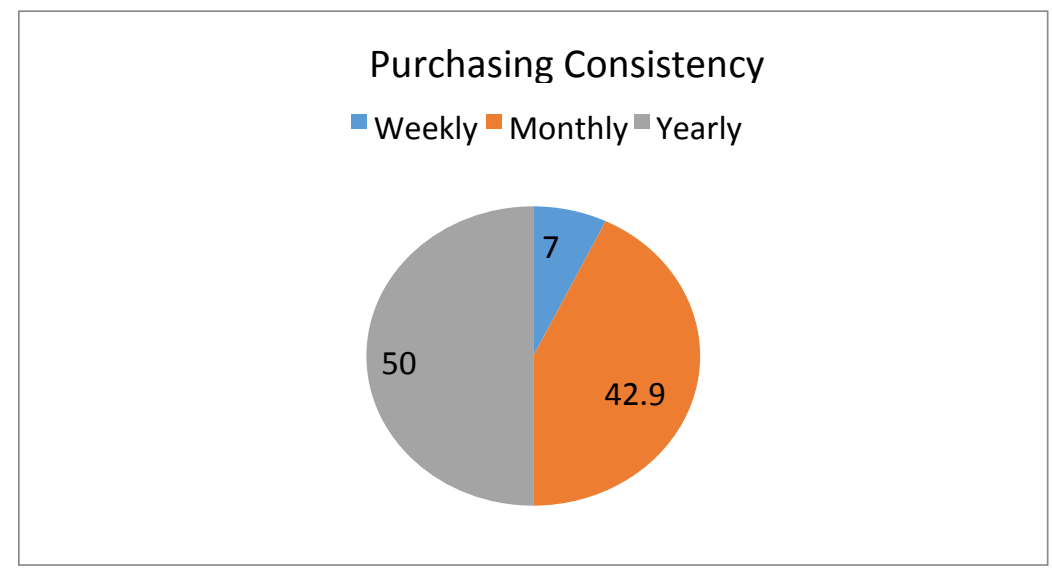

\section{Source: Primary Data}

Figure 5

The findings in figure 5 indicate that those that purchase sportswear on a yearly basis stand to be the majority at $50 \%$. These were followed by those that purchase on a monthly basis that stands at $42.9 \%$. This is an indicator that due to the incomes of the respondents, their purchasing power is limited to the extent of purchasing sports items at least once a year as presented by the majority of the respondents.

\section{Empirical Findings}

The overall objective of this study was to establish the utilization of National Identity Cards by the SMMEs in Uganda among their clients. The study findings in relation to the utilization were broken down and presented objective by objective as reflected below: 


\begin{tabular}{|c|c|c|c|c|c|c|}
\hline SN & Opinions/Statements & SA (\%) & $\mathrm{A}(\%)$ & $\mathbf{N}(\%)$ & $\mathrm{D}(\%)$ & SD (\%) \\
\hline \multicolumn{7}{|c|}{ Clients' Identification } \\
\hline 1 & $\begin{array}{l}\text { This company minds about seeking clients' particulars like } \\
\text { names and contact }\end{array}$ & - & $5(35.7)$ & - & $1(7.1)$ & $8(57.1)$ \\
\hline 2 & As a client, I would wish to share my details with this company & $4(28.6)$ & $7(50.0)$ & - & $1(7.1)$ & $2(14.3)$ \\
\hline 3 & I personally possess a Ugandan National Identity Card & 13(92.9) & $1(7.1)$ & - & & \\
\hline 4 & $\begin{array}{l}\text { Clients' National Identity Cards are commonly used to get } \\
\text { clients' details by this company }\end{array}$ & $2(14.3)$ & $2(14.3)$ & - & $4(28.6)$ & $6(42.9)$ \\
\hline 5 & $\begin{array}{l}\text { A client's National Identity Cards is ideal in provision of client's } \\
\text { details }\end{array}$ & & $6(42.9)$ & - & $7(50.0)$ & $1(7.1)$ \\
\hline \multicolumn{7}{|c|}{ Clients' Knowledge about Identification } \\
\hline 1 & You are aware of existence of this company's client database & $3(21.4)$ & $2(14.3)$ & $4(28.6)$ & & $5(35.7)$ \\
\hline 2 & Initiatives are in place to seek clients' details and contacts & $4(28.6)$ & $4(28.6)$ & $1(7.1)$ & $2(14.3)$ & $3(21.4)$ \\
\hline 3 & As a client, I can freely share my details with this company & $6(42.9)$ & $7(50.0)$ & - & $1(7.1)$ & - \\
\hline \multicolumn{7}{|c|}{ Links with clients } \\
\hline 1 & The clients' choices are known to this company & $3(21.4)$ & $7(50.0)$ & - & $2(14.3)$ & $2(14.3)$ \\
\hline 2 & Employees in this company are oriented in client management & $5(35.7)$ & $7(50.0)$ & - & - & $2(14.3)$ \\
\hline 3 & You can refer a friend to this company & $7(50.0)$ & $5(35.7)$ & - & $1(7.1)$ & - \\
\hline \multicolumn{7}{|c|}{ Business enhancement } \\
\hline 1 & Clients get to know about this company's products with ease & $7(50.0)$ & $6(42.9)$ & - & - & $1(7.1)$ \\
\hline 2 & Clients can contribute to stock control in this company & $5(35.7)$ & $9(64.3)$ & - & - & - \\
\hline 3 & Cases of theft and fraud are reported in this company & $6(42.9)$ & $3(21.4)$ & $1(7.1)$ & $2(14.3)$ & $2(14.3)$ \\
\hline 4 & $\begin{array}{l}\text { Clients help in the determination of business operations in this } \\
\text { company }\end{array}$ & $4(28.6)$ & $8(57.1)$ & - & $2(14.3)$ & - \\
\hline
\end{tabular}

Source: Primary Data

Table 2

Key

\begin{tabular}{|l|l|l|l|l|}
\hline SA & A & N & D & SD \\
\hline Strongly Agree & Agree & Neutral & Disagree & Strongly Disagree \\
\hline
\end{tabular}

\section{Clients' Identification}

The study aimed at finding out whether sports companies take an initiative into seeking clients' particulars especially names and contacts. This worked as an entry point into utilization of National Identity Cards that clients possess so that companies can utilize them. 
To this end, only $35.7 \%$ of the respondents agreed that their particulars are being sought by the sports companies. The remaining $64.2 \%$ majority of the respondents disagreed implying that the sports companies don't mind about the clients' particulars hence not utilizing the National Identity Cards in the segmentation of their businesses.

The study went ahead to assess whether the clients have a role to play in sharing their personal information relating to their identity. From the gathered information, majority of the respondents at $78.6 \%$ agreed (when combined- those that agreed and those that strongly agreed). This is an implication that the clients can willingly share their personal particulars with the sports companies. This therefore creates an opportunity for sports companies to identify their clients and segment their businesses using their clientele information.

For the sports companies to be in position to utilize their clients' National Identity Cards, the clients themselves have to be in possession of the same. The researcher therefore sought to find out if the clients/respondents had the National Identity Cards in their possession. From the gathered information, all the clients (100\%) possessed their National Identity Cards. However, at the time of carrying out the study, only $7.1 \%$ of the respondents was not with it at the moment of interacting with the researcher but possess it. This is an implication that majority of the sportswear clients in Uganda possess National Identity Cards that the sportswear companies need to utilize in identifying their clients.

The study tried to find out if the possessed National Identity Cards are actually used by the sports companies in identifying their clients. To this effect, $28.6 \%$ of the respondents agreed while majority of the respondents at $71.5 \%$ disagreed. This implies that little attention is paid on the utilization of National Identity Cards by the sports companies. In justification of this finding, $64.2 \%$ of the respondents had disagreed with the fact that the sports companies mind about seeking the particulars of their clients.

Finally, on identification of clients using their National Identity Cards, the researcher established that according to the clients, the National Identity Cards are not ideal in providing details of the clients. This was supported by the majority of the respondents at $57.1 \%$ that were in disagreement. Their argument was on the fact that some people's addresses keep changing and these changes are not quickly reflected and adjusted on their National Identity Cards.

\section{Clients' Knowledge about Identification}

For clients to be registered, they need to know whether the sports companies are in possession of the databases where the clients' details are being kept. To this effect, $35.7 \%$ of the respondents agree, $28.6 \%$ remained neutral while $35.7 \%$ were in disagreement. This is an implication that sports companies try to seek particulars of their clients but the clients are not aware of the existence of the companies' database. It further implies that the sports companies don't put a lot of emphasis on using the National Identity Cards in identifying their clients.

The clients showed interest in sharing their particulars once approached as reflected by the majority that agreed with the concept at $92.9 \%$. However, this is not fully utilized by the sports companies given that $57.2 \%$ agreed that there was an initiative by the sports companies to seek their details using their National Identity Cards.

\section{Links with clients}

Clients' choices being known by the sportswear companies was identified as a concept of having a link between the sportswear companies and the clients. In regard to this concept, $71.4 \%$ of the respondents agreed while $28.6 \%$ of the respondents disagreed. This implies that the companies are aware of the choices of their clients hence a link between the two- the companies and their clients.

Client care is one of the major concepts that the study identified under the links between the companies and their clients. The findings indicate that $85.7 \%$ of the respondents agreed with this concept, implying that the companies' client care is good and cherished by the clients as presented by the majority of the respondents in agreement. This was further justified by the fact that the majority of the respondents at $85.7 \%$ were willing to refer the companies to other people, to seek services from the same companies.

\section{Business enhancement}

The findings on business enhancement indicate that the clients get to know the companies' products with ease as $92.9 \%$ of the majority of the respondents agreed with this concept. In addition, all clients (100\%) agreed that they contribute to stock control of the sports companies implying that the companies stock basing on the preferences of their clients.

On the issue of fraud, it was reported that cases of fraud actually exist among the sports companies and the majority of the respondents at $64.3 \%$ agreed with this concept. This implies that the non-utilization of National Identity Cards by the sports companies facilitates the existence of fraud among the sports companies. 
It was also established that clients have a stake in determination of business operations given that $85.7 \%$ of the respondents agreed with the concept.

\section{Correlations}

Correlation analysis was used to get more substantial information between the use of National Identity Cards and fraud. The statistics generated the information that is reflected in the table below.

\section{Correlations}

\begin{tabular}{|ll|l|l|}
\hline & & Clientidty & Fraud \\
\hline Clientidty & $\begin{array}{l}\text { Pearson } \\
\text { Correlation }\end{array}$ & 1 & \\
& Sig. (2-tailed) & & .065 \\
& $\mathrm{~N}$ & 14 & 14 \\
\hline Fraud & Pearson & & \\
& Correlation & .065 & 1 \\
& Sig. (2-tailed) & .827 & \\
& $\mathrm{~N}$ & 14 & 14 \\
\hline
\end{tabular}

\section{Table 3}

The correlations between identification and fraud stand at 0.065 at a level of significance of 0.827 . This implies that as identification of clients takes a positive direction, fraud is also checked. There is currently a weak relationship between identification and checking fraud in the sports sector in Uganda that stands at 0.065.

\section{Regression}

The use of National Identity Cards by sports manufacturing companies in Uganda is still low. Once the utilization of National Identity Cards is strengthened, fraud can be checked since there is a positive correlation.

Model Summary

\begin{tabular}{|l|l|l|l|l|}
\hline & & & $\begin{array}{l}\text { Adjusted } \\
\text { Model }\end{array}$ & $\begin{array}{l}\text { Std. Error of } \\
\text { the } \\
\text { Estimate }\end{array}$ \\
\hline 1 & $.065^{\mathrm{a}}$ & .004 & -.079 & 1.08677 \\
\hline
\end{tabular}

Table 4

\section{a. Predictors: (Constant), Client identity}

In the Model Summary, the adjusted R of -0.079 implies that the independent Variable-Client Identity Card use accounts for $7.9 \%$ reduction of fraud among sports manufacturing companies.

\section{Coefficients $^{\mathrm{a}}$}

\begin{tabular}{|c|c|c|c|c|c|c|}
\hline \multirow[b]{2}{*}{ Model } & & \multicolumn{2}{|c|}{$\begin{array}{l}\text { Unstandardized } \\
\text { Coefficients }\end{array}$} & \multirow{2}{*}{$\begin{array}{l}\text { Standardized } \\
\text { Coefficients } \\
\text { Beta }\end{array}$} & \multirow[b]{2}{*}{$\mathrm{T}$} & \multirow[b]{2}{*}{ Sig. } \\
\hline & & $\mathrm{B}$ & Std. Error & & & \\
\hline 1 & (Constant) & 3.530 & 1.961 & & 1.800 & .097 \\
\hline & Clientidty & .118 & .529 & .065 & .224 & .827 \\
\hline
\end{tabular}

Table 5 
a. Dependent Variable: Fraud

In the Table above, client identity has a Standardised Coefficient Beta of 0.065. This implies that the independent variable-client identity accounts for $6.5 \%$ in checking fraud in sports manufacturing companies in Uganda.

Qualitative Report of Companies that have not adopted the use of National Identity Cards

Owner/Employee Interview Guide- Asiatic Sports Centre

The Company is yet to adopt the use of National Identity Cards in the management of its business.

Owner/Employee Interview Guide (Adidas)

The Company is yet to adopt the use of National Identity Cards, but is of the view that card readers would be useful to them to check fraud.

Quantitative Report for the Companies that have adopted the use of National Identity Cards.

Discussion

\begin{tabular}{|l|l|l|l|l|l|l|l|l|}
\hline Biodata & Variable & $\mathbf{\%}$ & Variable & $\mathbf{\%}$ & Variable & \% & Variable & \% \\
\hline Sex & Female & $70 \%$ & Male & $30 \%$ & & & & \\
\hline Age & $18-29$ & $20 \%$ & $30-39$ & $40.0 \%$ & $40-49$ & $30.0 \%$ & $50-59$ & $10.0 \%$ \\
\hline Education & Secondary & $5.0 \%$ & University & $25.0 \%$ & $\begin{array}{l}\text { Post } \\
\text { Graduate }\end{array}$ & $70.0 \%$ & & \\
\hline Income & LGX 500,000 & $10.0 \%$ & $\begin{array}{l}\text { UGX } \\
500,000999,000\end{array}$ & $20.0 \%$ & $1,000,000+$ & $70.0 \%$ & & \\
\hline $\begin{array}{l}\text { Telecom } \\
\text { companies }\end{array}$ & MTN & $40.0 \%$ & Airtel & $35.0 \%$ & Both & $25.0 \%$ & & \\
\hline $\begin{array}{l}\text { Purchasing } \\
\text { power }\end{array}$ & Daily & $90.0 \%$ & Weekly & $5.0 \%$ & Monthly & $5.0 \%$ & & \\
\hline $\begin{array}{l}\text { Mode of } \\
\text { payment }\end{array}$ & $\begin{array}{l}\text { Mobile money } \\
\text { and Cash }\end{array}$ & $95.0 \%$ & Cash & $5.0 \%$ & & & & \\
\hline
\end{tabular}

Table 6: Background information

Source: Primary Data.

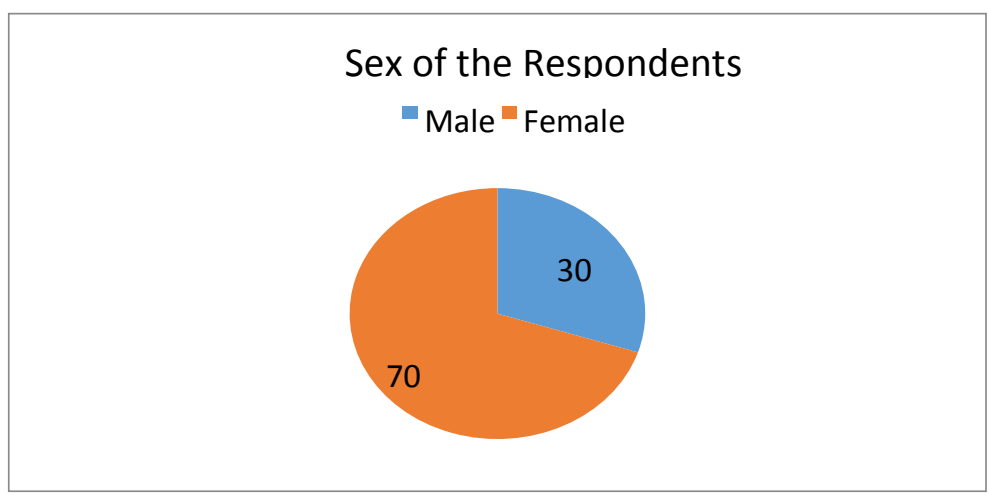

Figure 6: Sex of the Respondents

The findings in the figure above show that the majority of the respondents were females at $70 \%$ while males were $30 \%$. This is because of the random selection of the respondents that was employed by the study. In addition, the females showed a lot of willingness to attend to the researcher compared to their male counterparts. 


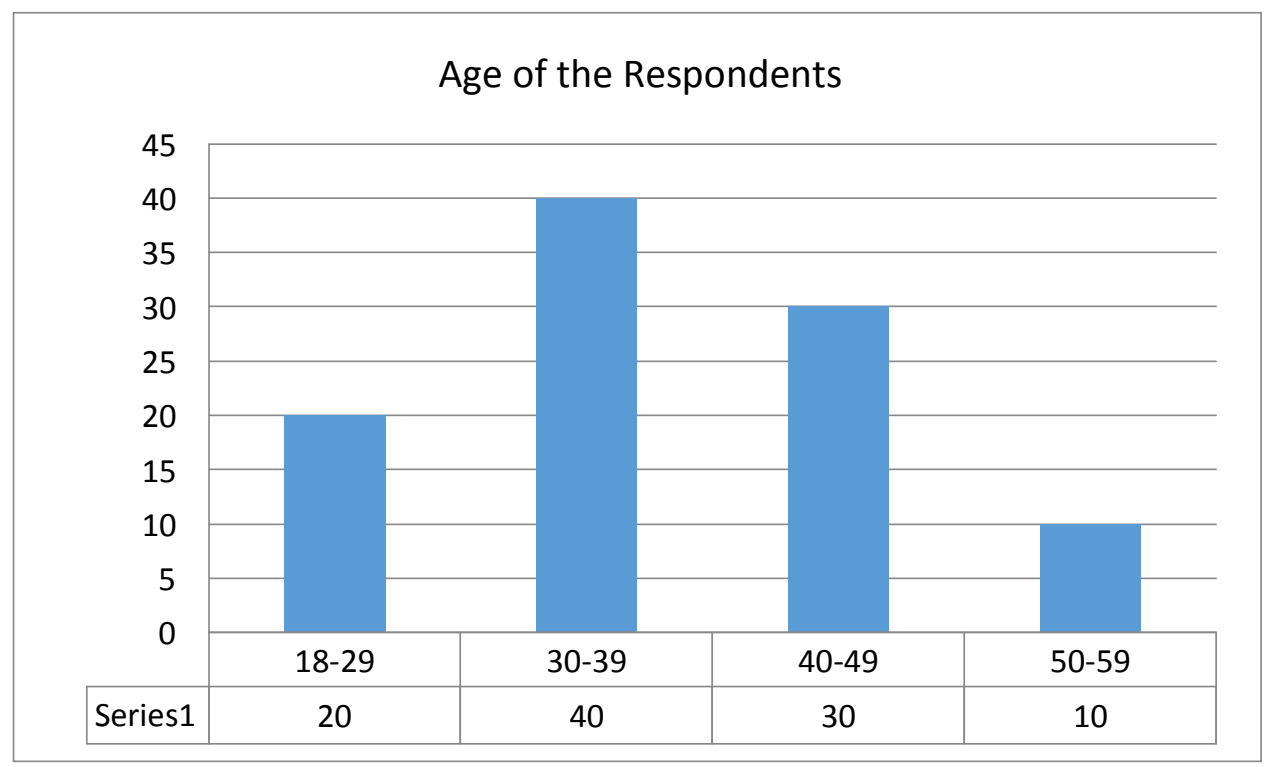

Figure 7: Age groups of the respondents

Fig. 7 above indicates the age groups of the respondents. The findings indicate that those in the age group of 18-29 were 20\%,30-39 were 40\%, 40-49 were 30\% and those between 50-59 stand at 10\%. Those in the age bracket of 30-39 stand out more than the rest age groups. This is because of their being more productive and more engaged in work and utilization of telecommunication services as compared to other indicated age groups.

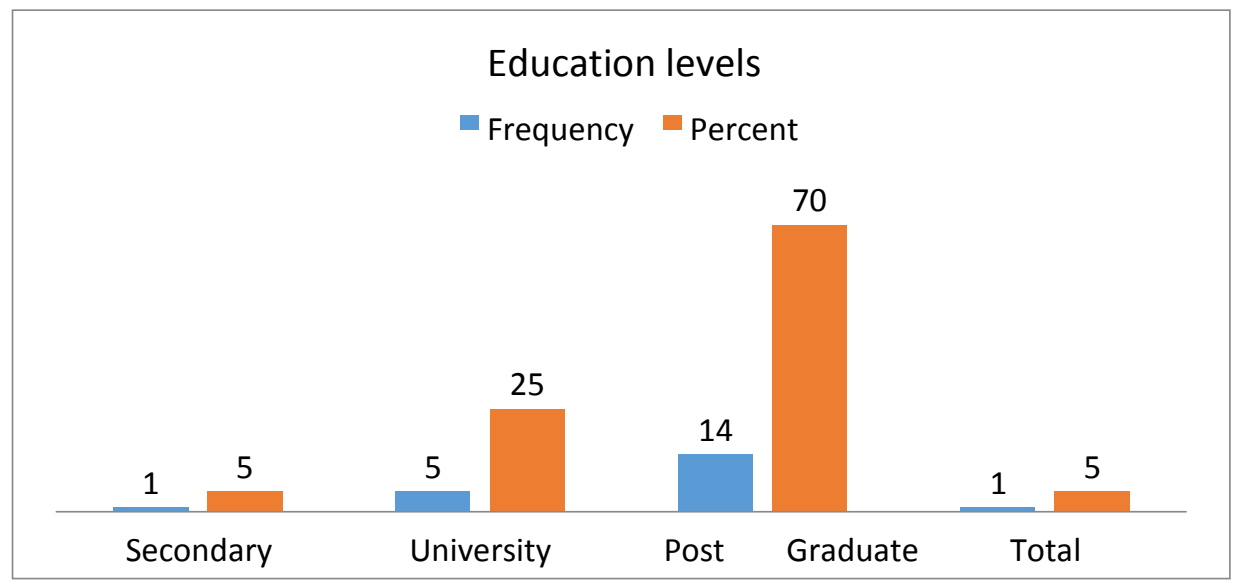

Figure 8: Academic Levels

The study was interested in the highest academic levels attained by the respondents. The findings in figure 8 above indicate that the majority of the respondents at $70 \%$ had attained a post-graduate academic level. 


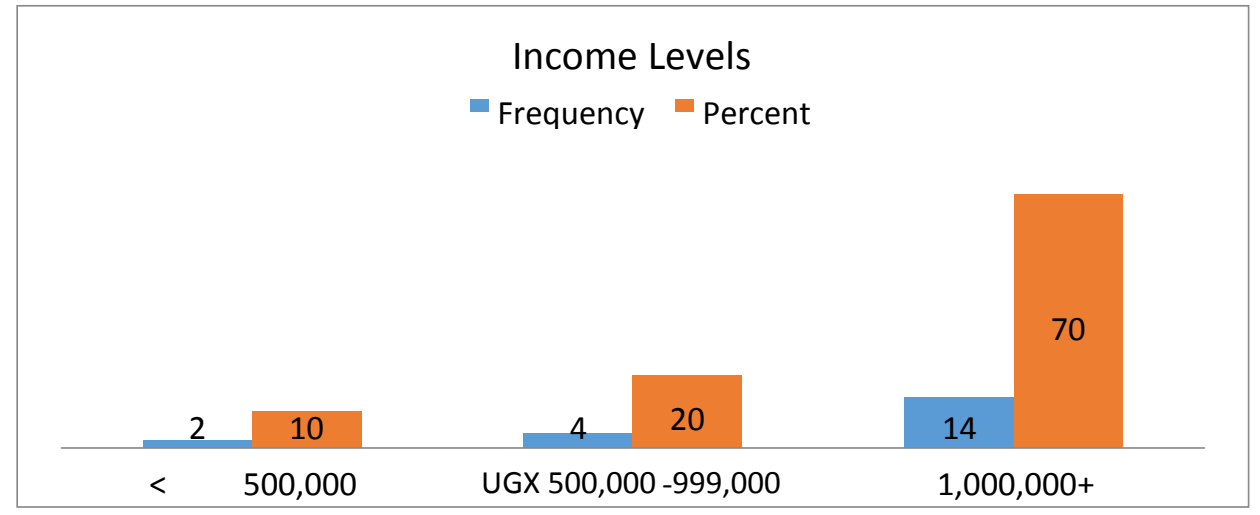

Figure 9: Income Levels

The income levels were used to establish the majority of the income level earners that highly purchase telecommunication services on a random selection. From the data gathered in the field, it indicates that majority of the respondents at $70 \%$ earn above One million Uganda shillings in their monthly income.

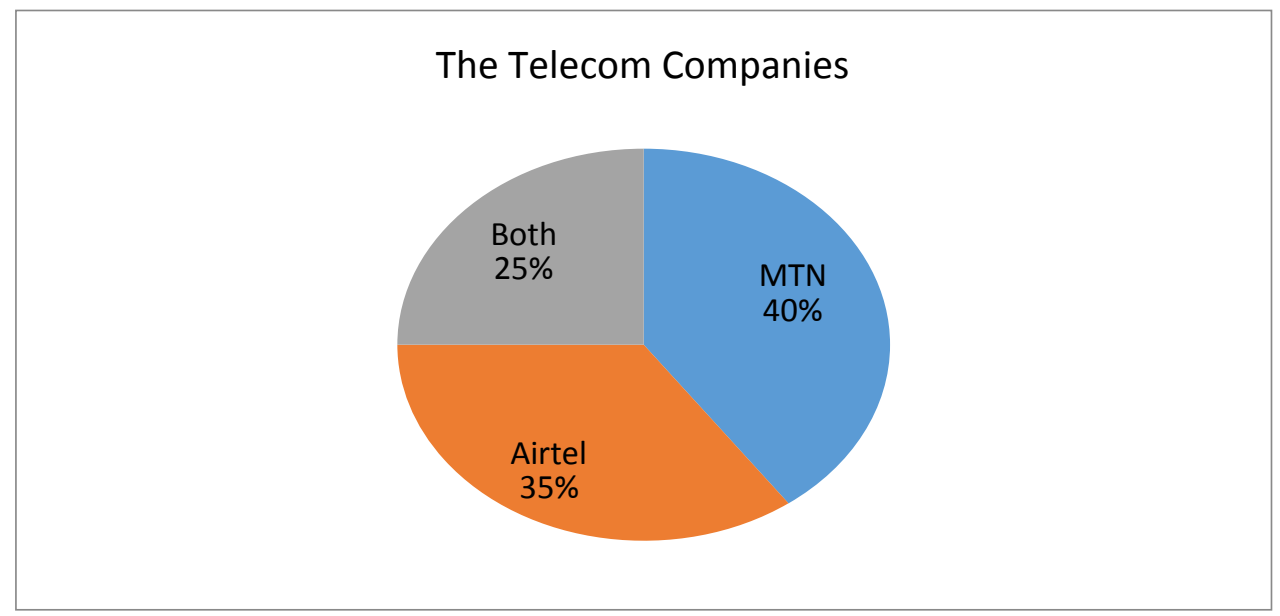

Figure 10: Telecom Companies

The researcher was interested in establishing the commonly utilized telecommunication company by the respondents. The findings in figure 10 indicate that MTN is represented by $40 \%$ of the respondents, Airtel has $35 \%$ and the rest of the respondents at $25 \%$ subscribe to both companies hence utilizing the services of the two companies.

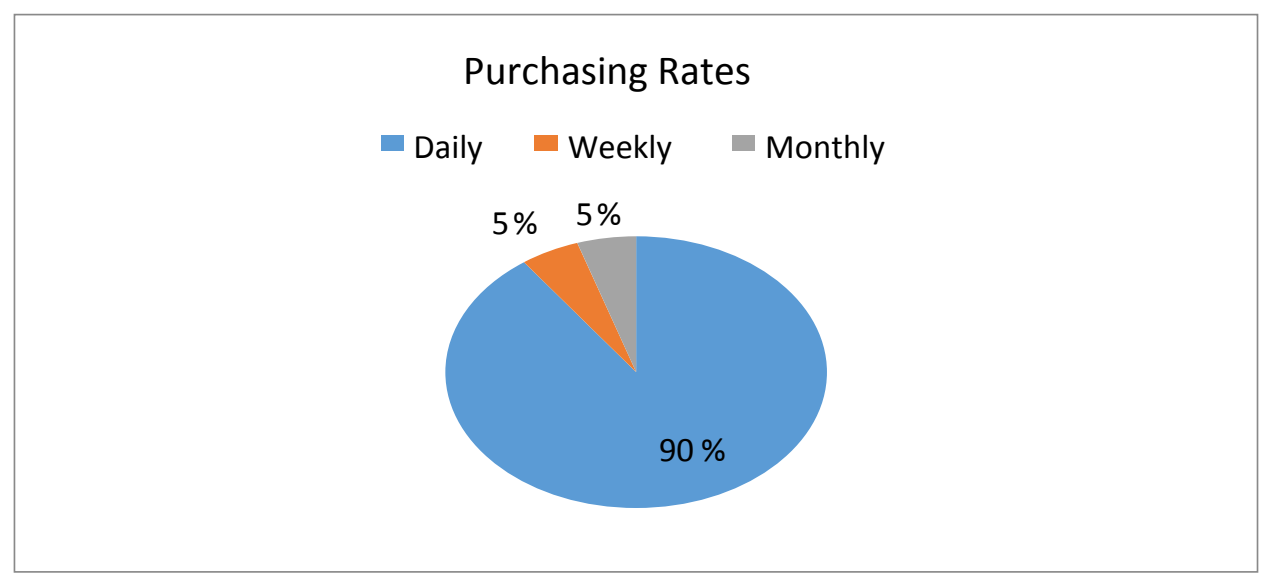

Figure 11: Purchasing Rate

The findings in Figure 11 indicate that majority of the respondents at $90 \%$ purchase telecommunication services on a daily basis. This implies that the information that they provided is fully based on their experience. 


\section{Empirical Findings}

\section{Introduction}

The overall objective of this study was to establish the utilization of National Identity Cards by the telecom companies in Uganda among their clients and how it impacts on business performance. The study findings in relation to the utilization were broken down and presented objective by objective and reflected as follows:

\begin{tabular}{|c|c|c|c|c|c|c|}
\hline $\mathbf{S N}$ & Opinions/Statements & SA (\%) & $\mathrm{A}(\%)$ & $\mathbf{N}(\%)$ & $\mathbf{D}(\%)$ & SD $(\%)$ \\
\hline \multicolumn{7}{|c|}{ Clients' Identification } \\
\hline 1 & $\begin{array}{l}\text { Your mobile telecommunication provider minds about } \\
\text { seeking clients' particulars like names and contact }\end{array}$ & 19(95.0) & $1(5.0)$ & - & - & - \\
\hline 2 & $\begin{array}{l}\text { As a client, I would wish to share my details with my } \\
\text { mobile telecommunication provider }\end{array}$ & $17(85.0)$ & $2(10.0)$ & - & - & $1(5.0)$ \\
\hline 3 & I personally possess a Ugandan National Identity Card & $14(70.0)$ & $5(25.0)$ & - & - & $1(5.0)$ \\
\hline 4 & $\begin{array}{l}\text { Clients' National Identity Cards are commonly used to } \\
\text { get clients' details by this company }\end{array}$ & $14(70.0)$ & $4(20.0)$ & - & - & $2(10.0)$ \\
\hline 5 & $\begin{array}{l}\text { A client's National Identity Card is ideal in provision of } \\
\text { client's details }\end{array}$ & $13(65.0)$ & $5(25.0)$ & - & - & $2(10.0)$ \\
\hline \multicolumn{7}{|c|}{ Clients' Knowledge about Identification } \\
\hline 1 & $\begin{array}{l}\text { You are aware of existence of your mobile } \\
\text { telecommunication provider's client database }\end{array}$ & $7(35.0)$ & $13(65.0)$ & - & - & \\
\hline 2 & Initiatives are in place to seek clients' details and contacts & $16(80.0)$ & $4(20.0)$ & - & & \\
\hline 3 & $\begin{array}{l}\text { As a client, I can freely share my details with this } \\
\text { company }\end{array}$ & $10(50.0)$ & $7(35.0)$ & - & $3(15.0)$ & \\
\hline \multicolumn{7}{|c|}{ Links with clients } \\
\hline 1 & The clients' choices are known to this company & $6(30.0)$ & $7(35.0)$ & - & $5(25.0)$ & $2(10.0)$ \\
\hline 2 & $\begin{array}{l}\text { Employees in this company are oriented in client } \\
\text { management }\end{array}$ & $7(35.0)$ & $11(55.0)$ & - & $1(5.0)$ & $1(5.0)$ \\
\hline 3 & You can refer a friend to this company & $9(45.0)$ & $10(50.0)$ & - & $1(5.0)$ & - \\
\hline \multicolumn{7}{|c|}{ Business enhancement } \\
\hline 1 & $\begin{array}{lcccc}\text { As clients you get to know about your } & \mathrm{m} \\
\text { telecommunication provider products with ease } & & \end{array}$ & $12(60.0)$ & $7(35.0)$ & - & $1(5.0)$ & - \\
\hline 2 & Clients can contribute to stock control in this company & $10(50.0)$ & $6(30.0)$ & - & $2(10.0)$ & $2(10.0)$ \\
\hline 3 & $\begin{array}{l}\text { Cases of theft and fraud are reported by your mobile } \\
\text { telecommunication service provider }\end{array}$ & $16(80.0)$ & $3(15.0)$ & - & $1(5.0)$ & - \\
\hline 4 & $\begin{array}{l}\text { Clients help in the determination of business operations } \\
\text { in this company }\end{array}$ & $13(65.0)$ & $5(25.0)$ & - & - & $2(10.0)$ \\
\hline
\end{tabular}

Table 7

Source: Primary data

Key

\begin{tabular}{|l|l|l|l|l|}
\hline SA & A & N & D & SD \\
\hline Strongly Agree & Agree & Neutral & Disagree & Strongly Disagree \\
\hline
\end{tabular}




\section{Clients' Identification}

The results show that $100 \%$ of the respondents agree with the concepts that the telecommunication companies mind seeking their clients' details a lot.

In addition, $95 \%$ of the respondents wish to share their details with the telecommunication companies. On the issue of National Identity Card possession, 95\% of the respondents possessed National Identity Cards.

The respondents further indicated that the National Identity Cards were commonly used by the respondents at $90 \%$, and lastly, $90 \%$ of the respondents agreed with the fact that the National Identity Cards were ideal in capturing the clients' details. This is an implication that the telecommunication companies actually utilize the information of the National Identity Cards in Uganda to identify their clients. In the utilization of the National Identity Cards, clients of the telecom companies possess the National Identity Cards and they were reported to be ideal in accessing ideal information about the clients.

\section{Clients' Knowledge about Identification}

The study considered clients' knowledge about the importance of their identification with the telecommunication companies through the use of the National Identity Card as a second study objective. This was carried out since those that are being identified or whose details are being sought need to be aware of their details being sought and why. From the findings, it was established that all the clients are aware that their telecom service providers have a database of their details that their particulars as clients are being sought by the telecom services and further that they freely share their details. This is an implication that the telecommunication companies have fully embraced the use of the National Identity Cards of clients and the clients appreciate the reasons as to why their details are being sought by the telecom service providers.

\section{Links with clients}

The study wanted to establish whether the identification of clients creates a link between the telecom companies and their clients in Uganda. Using a frequency and percentage analysis, majority of the clients at $65 \%$ agreed with the fact that the telecom companies knew their choices. On the issue of client management, $90 \%$ majority of the respondents agreed that the telecom companies exhibit good client care and another 95\% agreed when it comes to referring new clients to their service providers. This is an implication of the use of National Identity Cards by the telecom sector in business segmentation whereby client care and understanding of their choices can be realized through specific identification of their clients.

\section{Business enhancement}

Business enhancement was established as having been propelled by the client identification done by the telecom companies. The study realized that clients are aware of the companies' products and they get to know with ease basing on the response of the majority of the respondents that agreed at $95 \%$. Another $80 \%$ of the respondents agreed with the fact that they contribute to the operations of the business. The utilization of the National Identity Cards by the telecom companies makes it possible to segment their businesses as they are directly linked to their clients.

On the issue of fraud, the respondents at the majority of 95\% agreed with the fact that fraud is reported in the telecom sector. This is an implication that the use of National Identity Cards can be crucial in checking fraud in the telecom sector as they may utilize the information provided by the National Identity Cards to investigate the crime. 


\section{Correlations}

\section{Correlations}

\begin{tabular}{|ll|l|l|}
\hline & & & \\
& & Identification & Customer care \\
\hline Identification & Pearson Correlation & 1 & .026 \\
& Sig. (1-tailed) & & .457 \\
& $\mathrm{~N}$ & 20 & 20 \\
\hline Customer care & Pearson Correlation & .026 & 1 \\
& Sig. (1-tailed) & .457 & 20 \\
& $\mathrm{~N}$ & 20 & \\
\hline
\end{tabular}

\section{Table 8}

The correlation results indicate that client identification and customer care have a positive correlation of 0.026 at a significance of 0.457 . A positive correlation implies that as client identification increases, customer care also increases. However, the correlation of 0.026 is a weak correlation. This implies that currently, the client identification has a weak relationship with customer care in the telecommunication sector of Uganda.

Correlations

\section{Correlations}

\begin{tabular}{|c|c|c|c|}
\hline & & Identification & Fraud \\
\hline \multirow[t]{3}{*}{ Identification } & $\begin{array}{l}\text { Pearson } \\
\text { Correlation }\end{array}$ & 1 & $.697^{* * *}$ \\
\hline & Sig. (2-tailed) & & .001 \\
\hline & $\mathrm{N}$ & 20 & 20 \\
\hline \multirow[t]{3}{*}{ Fraud } & $\begin{array}{l}\text { Pearson } \\
\text { Correlation }\end{array}$ & $.697^{* * *}$ & 1 \\
\hline & Sig. (2-tailed) & .001 & \\
\hline & $\mathrm{N}$ & 20 & 20 \\
\hline
\end{tabular}

Table 9

**. Correlation is significant at the 0.01 level (2-tailed).

The correlations between identification and fraud stand at 0.697 at a level of significance of 0.001 . This implies that as identification of clients takes a positive direction, fraud is also checked. There is currently a strong relationship between identification and checking fraud in the telecommunication sector in Uganda that stands at 0.697. 
Correlations

\begin{tabular}{|ll|l|l|}
\hline & & Identification & Segmentation \\
\hline Identification & $\begin{array}{l}\text { Pearson } \\
\text { Correlation } \\
\end{array}$ & 1 & -.048 \\
& Sig. (2-tailed) & & .841 \\
& $\mathrm{~N}$ & 20 & 20 \\
\hline Segmentation & $\begin{array}{l}\text { Pearson } \\
\text { Correlation }\end{array}$ & -.048 & 1 \\
& Sig. (2-tailed) & .841 & \\
$\mathrm{~N}$ & 20 & 20 \\
\hline
\end{tabular}

Table 10

The results in the table above indicate that the correlation between identification and business segmentation is -0.048 at a significant level of 0.841 . This shows that there is a weak negative relationship between client identification and business segmentation in the telecommunication sector in Uganda. As client identification takes a positive direction/increases, business segmentation decreases.

\section{Regression}

\section{Model Summary}

\begin{tabular}{|l|l|l|l|l|}
\hline Model & $\mathrm{R}$ & $\mathrm{R}$ Square & $\begin{array}{l}\text { Adjusted } \\
\text { Square }\end{array}$ & $\begin{array}{l}\text { Std. Error of } \\
\text { the } \\
\text { Estimate }\end{array}$ \\
\hline & & & & \\
1 & $.026^{\mathrm{a}}$ & .001 & -.055 & .94560 \\
\hline
\end{tabular}

Table 11

a. Predictors: (Constant), Identification

From the model summary, the study found out that Identification as a dimension of the Independent Variable has an Adjusted R Square of -0.055. This means that as a dimension of the Independent Variable, it accounts for 5.5\% of the Dependent variable- Customer Care. This implies that client identification reduces customer care in the telecommunication industry in Uganda by $5.5 \%$.

Coefficients ${ }^{\mathrm{a}}$

\begin{tabular}{|ll|l|l|l|l|l|}
\hline & & \multicolumn{2}{|l|}{$\begin{array}{l}\text { Unstandardized } \\
\text { Coefficients }\end{array}$} & $\begin{array}{l}\text { Standardized } \\
\text { Coefficients }\end{array}$ & & \\
\cline { 3 - 4 } Model & $\mathrm{B}$ & Std. Error & Beta & $\mathrm{t}$ & Sig. \\
\hline 1 & $\begin{array}{l}\text { (Constant) } \\
\end{array}$ & 3.846 & 1.277 & & 3.011 & .007 \\
& Identification & .030 & .276 & .026 & .109 & .914 \\
\hline
\end{tabular}

Table 12

a. Dependent Variable: Customer care 
The findings in the table above indicate that the dimension of the Independent Variable- client identification has a standardized coefficient Beta (B) of 0.026. This implies that client identification contributes to customer care in the telecommunication industry in Uganda by $2.6 \%$.

Model Summary

\begin{tabular}{|l|l|l|l|l|}
\hline & & & $\begin{array}{l}\text { Adjusted } \\
\text { Sodel }\end{array}$ & $\begin{array}{l}\text { Std. Error of } \\
\text { the } \\
\text { Estimate }\end{array}$ \\
\hline & $\mathrm{R}$ & R Square & Square \\
1 & $.697^{\mathrm{a}}$ & .486 & .457 & .53982 \\
\hline
\end{tabular}

Table 13

\section{a. Predictors: (Constant), Identification}

From the model summary, the study found out that Identification as a dimension of the Independent Variable has an Adjusted R Square of 0.457. This means that as a dimension of the Independent Variable, it accounts for $45.7 \%$ of the Dependent variable- checking of fraud. This implies that client identification contributes to fraud detection and management in the telecommunication industry in Uganda at $45.7 \%$.

\section{Coefficients $^{\mathrm{a}}$}

\begin{tabular}{|c|c|c|c|c|c|c|}
\hline \multirow{2}{*}{\multicolumn{2}{|c|}{ Model }} & \multicolumn{2}{|c|}{$\begin{array}{l}\text { Unstandardized } \\
\text { Coefficients }\end{array}$} & \multirow{2}{*}{$\begin{array}{l}\text { Standardized } \\
\text { Coefficients } \\
\text { Beta }\end{array}$} & \multirow[b]{2}{*}{$\mathrm{t}$} & \multirow[b]{2}{*}{ Sig. } \\
\hline & & $\mathrm{B}$ & Std. Error & & & \\
\hline \multirow[t]{2}{*}{1} & (Constant) & 1.735 & .729 & & 2.380 & .029 \\
\hline & Identification & .650 & .158 & .697 & 4.123 & .001 \\
\hline
\end{tabular}

Table 14

a. Dependent Variable: Fraud

The findings in the table above indicate that the dimension of the Independent Variable- client identification has a standardized coefficient Beta (B) of 0.697. This implies that client identification contributes to fraud management in the telecommunication industry in Uganda by $69.7 \%$.

Regression

Model Summary

\begin{tabular}{|l|l|l|l|l|}
\hline & & & $\begin{array}{l}\text { Adjusted } \\
\text { Model }\end{array}$ & $\begin{array}{l}\text { Std. Error of } \\
\text { the } \\
\text { Estimate }\end{array}$ \\
\hline 1 & $.048^{\mathrm{a}}$ & .002 & -.053 & .98816 \\
\hline
\end{tabular}

Table 15

\section{a. Predictors: (Constant), Identification}

From the model summary, the study found out that client identification as a dimension of the Independent Variable has an Adjusted R Square of -0.053. This means that as a dimension of the Independent Variable, it accounts for 5.3\% of the Dependent variable- business segmentation. Having indicated a negative Adjusted R square, it implies that client identification affects business segmentation in the telecommunication sector by $5.3 \%$ in Uganda. 


Coefficients $^{\mathrm{a}}$
\begin{tabular}{|ll|l|l|l|l|l|}
\hline \multicolumn{2}{|c|}{} & \multicolumn{2}{|l|}{$\begin{array}{l}\text { Unstandardized } \\
\text { Coefficients }\end{array}$} & $\begin{array}{l}\text { Standardized } \\
\text { Coefficients }\end{array}$ & & \\
Model & & B & Std. Error & Beta & $\mathrm{t}$ & Sig. \\
\hline 1 & (Constant) & 4.551 & 1.335 & & 3.410 & .003 \\
& Identification & -.059 & .288 & -.048 & -.203 & .841 \\
\hline
\end{tabular}

Table 16

a. Dependent Variable: Segmentation

The findings in the table above indicate that the dimension of the Independent Variable- client identification has a standardized coefficient Beta (B) of -0.048 . This implies that client identification affects business segmentation in the telecommunication industry in Uganda by $4.8 \%$.

\section{Qualitative Report for companies that have adopted the use of National Identity Cards}

\section{An exclusive interview with the MTN Key Respondent}

The National Identity Card has improved integrity in the sector-there is now more confidence in doing business with the sector. In the Case Management system, it gives credibility to the quality of evidence being adduced in courts of law. Further, it has also led to segmentation of businesses through creation of services like borrowing of airtime and mobile money services.

The National Identity Card has improved on usability of the services. The company has a direct link and knowledge of the customers. The company understands the customers' profiles and responds to their demands on an individual basis and to specific individuals. There is a link created for the customer and what they want most. There is data that enables the company to tailor packages that makes sense to specific individuals.

\section{Policy suggestions}

There should be policies that should ensure regulated prices in the telecommunication sector to enhance fair competition among different players and ensure sensitivity to users. For example, there are users in the hard to reach areas. The government needs to monitor the telecommunication companies to see how to assist such individuals.

There is a need to entice the private sector to reach these hard to reach areas through provision of services like roads, electricity and security.

\section{An exclusive Interview with Key correspondent in Airtel}

There has been a decreased number of customers since the Company adopted the use of National Identity Cards. This is against the backdrop that some customers are not registered with NIRA and yet this is now a prerequisite before one registers with a telephone company. The company has not yet identified the use of National Identity Cards in business segmentation but it can help in availing information like among others, age, which can be used in establishing specific products for them. The National Identity Card can also be used in identifying fraud.

\section{Conclusion, Limitations and Recommendations}

\section{Conclusion}

The research has shown that the National Identity Card is one of the performance measurement tools for identifying identity fraud in Companies. And further that, for Companies that have adopted the use of National Identity Card in their businesses and even those that have not, there is the potential that this Card can enhance the performance of businesses. Specifically, this can be done through streamlining business processes in order to curb fraud as well as provide for client and business segmentation. 


\section{Limitations}

However, the existence of this national identifier and integrated government information system that may build around it, raises fear that potential future authoritarian governments may use it as a weapon of mass control (the Guardian, 2003). Moreover, its introduction poses a challenge to data protection, data privacy and public trust in information governance (Beynon, 2007). Further, although biometric systems are normally deemed to be a secure and convenient method of building identifiers that satisfy many of the characteristics of good identification systems, they are not foolproof since they can make two types of errors (Zorkadis and Donos, 2004): false match and false rejection. Nevertheless, the National Identity Card offers numerous potential benefits for individuals and organizations.

\section{Recommendation}

There is definitely need for further discussions/research on identity and fraud in companies. Indeed, Clough (2015) reiterates this and expounds that although there is currently no international instrument which specifically and comprehensively addresses identity theft, there is need for further international discussion as to the desirability and form of identity theft provisions-to enable Countries develop appropriate legal frameworks and capacity to address the modern fraud environment. Kramer (2015) also confirms that External Audits by Certified Public Accountants cannot be relied upon to detect fraud. And further that owners, managers and advisors are strongly encouraged to have knowledge of how fraud can affect their organizations in order to prevent or detect fraud and avoid devastating effect it can have on business viability.

\section{References}

Beynon-Davis, P. (2007). "Personal Identity Management and Electronic Government. The Case of the National Identity Card in the UK", Journal of Enterprise Information Management, Vol.20 Iss.3 PP.244-270.

Burnham, D. (1983). The Rise of the Computer State, Random House New York, NY. (Google scholar).

Bwambale, T. (2018, November) "Ugandans with National IDs to get passports with ease". The New Vision. Retrieved from https://www.newvision.co.ug.news.

Clark, R. (1994), "Human identification in information systems: management challenges and public policy issues", Information Technology \& People, vol.7 No.4.

Clough, J. (2015). "Towards a Common Identity? The Harmonization of Identity Theft Laws", Journal of Financial Crime, vol.22 Issue:4, pp.492-512, https://doi.org/10.1108/JFC-11-2014-0056.

Cocca, P., Alberti, M. (2010). "A Framework to Assess Performance Measurement Systems in SMEs", International Journal of Productivity and Performance Management, vol.59 Iss.2, pp.186-200.

Darmall Nicole, Sadorsky Perry and Henrique Irlue, 2009, Adopting proactive strategy; the influence of stakeholders and firm size, Journal of Management Studies, Fair fax, USA.

Guardian (2003), Explained: ID cards, Guardian Unlimited, Manchester.

Kahungu, M. T. (2019, February 6). "NIRA starts massive 3- months registration for IDs". Daily Monitor.

Karugaba, M. and Walubiri, M. (2015, November 3). "2.5 Million National IDs Uncollected". The New Vision.

Kwesiga, P. (2018, April 8). "NIRA starts registering children for ID numbers". The New Vision.

Kramer, B. (2015). "Trust, but verify: Fraud in Small Businesses", Journal of Small Businesses and Enterprise Development, vol.22 issue: 1, pp.4-20, https:doi. org/10.1108/JSBED-08-2012-0097.

Lynch, R., and Cross, K. (1991). Measure Up! Yardsticks for Continuous Improvement, Basil Blackwell Inc, Cambridge, MA.

Magara Murder: Vendors remanded over SIM Cards(May,2018). The New Vision p.12.

National NGO Forum (2014). My Country My Identity. Report on the briefing session on the National Identity Card Project by Ministry of Internal Affairs and CSO leaders. Available online http://ngoforum.org.ug/wpcontent/uploads/downloads/2014/02/Report-on the-briefing-sessionbetween-theMinistry-of-internal-Affairs-and-CSO-Leaders-on-the National-ID-Project-1-1 pdf.

Robson, C. (2002). Real World Research (2nded.). London, UK; Blackwell Publishers.

Seifert, J. W. (2004). "Data Mining and the Search for Security: Challenges for Connecting the Dots and Databases." Government Informative Quarterly, vol.21 no.4, pp.461-81. (Google scholar) (cross ref) (181) (Infortrieve).Student Registration to end in December. (2017, October). The New Vision. P.5

Thompson, B. (2004). Who Do You Think You Are? BBC News Online, London (Google scholar).

Turker, M., Pitt, M. (2009). "Customer Performance Measurement in Facilities Management": A Strategic Approach" International Journal of Productivity and Performance Measurement, vol. 58, pp.407-422.

Wassajja, N. (2018, May 4) "NIRA to share citizen's data". The New Vision. 
Wettstein, T., \& Kueng, P. (2002). A Maturity Model for Performance Measurement Systems. Managements Information Systems, 113-122.

Zubolf, S. (1988). In the Age of the Smart Machine: The Future of Work and Power, Heinemann, London. (Google scholar)

Zorkadis, V. and Donos, P. (2004). "On Biometric-Based Authentication and Identification from a Privacy Protection Perspective: Deriving Privacy-Enhancing Requirements", Information Management and Computer Security, vol.12 No.1, pp.125-37. (link),(Google Scholar) (Infotrieve) 